\title{
Sound Pollution Effect, on Fish Mortality Rate in Tank Experiment
}

\author{
NTE and Felix Ugbana \\ ${ }^{1}$ Environmental Physics, ${ }^{2}$ Department of Physics \\ Faculty of Science \\ University of Port Harcourt \\ Port Harcourt, Rivers State \\ Nigeria
}

\begin{abstract}
The importance of physics in the study of life science cannot be overemphasized. In the light of diminishing aquatic biota by many pollutants, this study seeks to determine the impact of sound on selected tropical fish species using tank experimental method. The species include; X - Tilapia, $Y$ - Topminnow and Z - Clarias. The Physics behind it is that wildlife reacts to the environmental stressor in many ways. Fish do so by increasing kinetic energy via adrenal secretion. This, in turn, increases the frictional rate and possible rise in temperature and increase bio-oxygen demand, exhaustion, Hypovolemia, and hydrogen ion (acidosis). Furthermore is the fact that the impact of sound is a function of the density of the media, which is 5 times in water: as to the value in air. The statistical result shows the relationship between Tilapia and Topminnows at P value less 0.01 but a divergence in clarias because it can take in atmospheric oxygen directly. The opthopsy is indicative of oxygen deficiency due to air gap mouth. The conclusion is the steady noise of 87 Decibel $(d B A) \pm 5$ can increase the mortality rate of aquatic life over time while the noise level above 150dBA by seismic can lead to massive destruction. The major statistical tool is [1], which range as follows; 0.00 to 0.20 (Slight), 0.21 to 0.40 (Fair), 0.41 to 0.60 (Moderate), 0.61 to 0.80 (Substantial), 0.81 to 1.00 (Almost Perfect), also called Level of reliability. The intra relationship between the experimental and control groups are shown in Table 1.0 using Pearson Correlation. Table 4, however, shows a significant difference between the experimental fish mortality rate and the control, at $P$. value of 0.004 due to sound impact but not exclusive to other environmental parameters like temperature and dissolved oxygen level.
\end{abstract}

Key Words: Sound, Pollution, Noise, Aquaculture, Acoustics.

\section{INTRODUCTION}

Sound pollution effect on fish mortality rate in tank experiment is an off shoot of a doctoral research thesis on "sound pollution effect on the flora, fauna and structures in the Niger Delta sub-regions of Nigeria". The findings by simple averaging taking an average industrial noise of 87 Decibel $(d B A) \pm 5$ on the entire experiment at Agip gas plant and 55 Decibel $(d B A) \pm 5$ at the control shows:

A $24 \%$ reduction in plant fruit yield due to reduction in insect pollinating agent and general reduction in reproduction of the fauna, due to migration, and reduction in weight associated with locomotion and stress.

A $5 \%$ gain in sprouting or germination time of plants due to vibration impact and slightly elevated temperature of the experimental site by 2 Centigrade $\left({ }^{\circ} \mathrm{C}\right)$, which can be exploited.

A $44 \%$ danger on the survival of fishes, aquatic organism and wild life due to exposure risk of migration from sound pollution and a $2.5 \%$ chances of adaptation on each blast or sounding if it is not lethal and the environment is friendly.

A $14 \%$ reduction in learning or performance rate due to distraction or divided attention by an $87 \mathrm{dBA} \pm 5$ noise, but normal condition for 55 Decibel $(d B A) \pm 5$ at the control. 
The research projects a 15\% world annual increase in noise impact from baseline, taking an annual population grown rate of $3 \%$, multiply by the 5 sense organ of man competing for the task of the brain, using pressure principle.

The research established a sensitivity index of 1:5: $X>10$ for air, water and solid respectively

Where ' $\mathrm{X}$ ' implies: marine ecology and benthic communities of the bottom sediment using density and speed of sound in air to be about 332 Meters/Seconds (m/s), 1,540 Meters/Second (m/s) in sea water and 3,650 Meters/Second (m/s), in alloy by seismic principle.

Thus:

Speed of wave "C" in media

$\mathrm{C}=\sqrt{ }(1.401 \mathrm{p} / \rho)$

Where $\mathrm{C}=$ Speed of sound at a given temperature in meters per second $(\mathrm{m} / \mathrm{s})$

$\mathrm{P}=$ Air pressure in Newton/square Meter $\left(\mathrm{N} / \mathrm{m}^{2}\right)$ or Pascal $(\mathrm{Pa})$

$\rho=$ Air density in kilograms $/$ cubic Meter $\left(\mathrm{kg} / \mathrm{m}^{3}\right)$

$1.401=$ The ratio of the specific heat of air under constant pressure to that of air in a constant volume.

For a given air temperature and relative humidity, the ratio $\mathrm{p} / \rho$ tends to remain constant in the atmosphere because the density of air will reduce or increase proportionately with change in pressure.

The research further shows that the impact of noise is not just limited to the intensity but the frequency and other acoustic and environmental phenomenon which include the ecological fragility and sensitivity index. E.g. the Lake Mangrove ecology or games reserve.

The present study on fish mortality shows that sound increases the mortality rate of fishes by migration and increase biooxygen dement in a tank experiment. It is established that while $\mathrm{X}=$ Tilapia, $\mathrm{Y}=$ Topminnows are worst hit and will require open space for proper aeration, $\mathrm{Z}=$ Clarias can survive a confined environment by taking atmospheric oxygen and is recommend as best of the three for aquaculture. The table size and fast growth rate also favours aquaculture as a major source of protein and biomass Few studies to show that noise is a silent killer, include; [2 - 14].

\section{METHOD}

The method includes sourcing for the selected fish species at African regional aqua centre in Aluu, into a $60 \times 30 \times 15 \mathrm{~cm}$ Perspex experimental tank filled to $\frac{1}{3}$ the volume. These were placed at an 87 Decibel $(d B A) \pm 5$ generator sources and 55 Decibel $(d B A) \pm 5$ control site. The sample site is 50 fingerlings of each species while dead ones were immediately removed to avoid fouling of the water, without replacement.

\section{RESULT AND DISCUSSION}

A lot of parameters where considered during the analysis using the characterization of [15].

Table 1. Fish Mortality rate for both tank experimental and control

\begin{tabular}{|c|c|c|c|c|c|}
\hline Response & Mean & Std. Deviation & $\begin{array}{c}\text { Std. Error } \\
\text { Mean }\end{array}$ & Correlation (p-values) & $\begin{array}{c}\text { Level of } \\
\text { reliability }\end{array}$ \\
$\begin{array}{c}\text { SPX } \\
\text { Treatment }\end{array}$ & 3.67 & 3.68 & 1.06 & $0.610(0.035)^{* * *}$ & Moderate \\
\cline { 1 - 4 } SPX Control 1 & 2.58 & 3.58 & 1.03 & \multirow{2}{*}{$0.848(0.000)^{* * *}$} & Substantial \\
\hline SPY & 1.92 & 2.02 & 0.58 & \\
\hline
\end{tabular}


International Journal of Advances in Scientific Research and Engineering (ijasre), Vol 5 (4), April-2019

\begin{tabular}{|c|c|c|c|c|c|}
\hline $\begin{array}{c}\text { SPZ } \\
\text { Treatment }\end{array}$ & 0.08 & 0.29 & 0.08 & & - \\
\cline { 1 - 3 } SPZ Control 3 & 0.00 & 0.00 & 0.00 & & \\
\hline
\end{tabular}

Footnote: sig. at $*=10 \%, * *=5 \%$ and $* * *=1 \% ; \mathrm{X}=$ Tilapia; $\mathrm{Y}=$ Top Minnow; $\mathrm{Z}=$ Clarias

The result in table 1 shows significance relationship between the experimental fish morality rate and control groups at all significance levels since the p-values are less than 0.01; except (Clarias) and its control groups.

Table 1 also shows moderate correlation between the treatment groups (Tilapia) and the control groups, while the treatment groups (Top Minnow) and the control groups' shows Substantial relationship.

In addition, the relationship among the entire experimental fish morality rate and control groups was done in table 2 .

Table 2. Fish mortality rate between total experimental and control groups

\begin{tabular}{|c|c|c|c|c|}
\hline Response & Mean & Std. Deviation & Std. Error Mean & Correlation (p-values) \\
\hline SPX Treatment & 5.67 & 5.34 & 1.54 & $0.744(0.006)^{* * *}$ \\
\hline SPX Control 1 & 4.17 & 5.13 & 1.48 & \\
\hline
\end{tabular}

Footnote: sig. at $*=10 \%, * *=5 \%$ and $* * *=1 \%$; $\mathrm{X}=$ Tilapia; $\mathrm{Y}=$ Top Minnow; $\mathrm{Z}=$ Clarias

Table 2 shows significance relationship between the total experimental fish morality rate and control groups at all significance levels since the p-values are less than 0.01 .

Next, the correlation between the treatments group was done in figure 1 . and table 3 .

Figure 1.0: Pearson Correlation results between treatments group

\section{SPX Treatment SPY Treatment SPZ Treatment}

SPX Treatment

Sig. (2-tailed)

SPY Treatment

Sig. (2-tailed)

SPZ Treatment

Sig. (2-tailed)
1
$.730^{* * *}$

.007

.029

.930
.007

1

.968

.013

1

Footnote: ${ }^{* * *}$. Correlation is significant at the 0.01 level (2-tailed).

Table 3. Fish mortality rate between experimental groups

\begin{tabular}{|c|c|c|}
\hline Treatments & Correlation (p-values) & Level of reliability \\
\hline SPX Treatment/ SPY Treatment & $0.730(0.007)^{* * *}$ & Substantial \\
\hline SPX Treatment/ SPZ Treatment & $0.29(0.930)^{* * *}$ & Fair \\
\hline SPY Treatment /SPZ Treatment & $0.13(0.968)^{* * *}$ & Slight \\
\hline
\end{tabular}

Footnote: sig. at $*=10 \%, * *=5 \%$ and $* * *=1 \% ; \mathrm{X}=$ Tilapia; $\mathrm{Y}=$ Top Minnow; $\mathrm{Z}=$ Clarias

In table 3 only Tilapia against Top Minnow showed substantial level of reliability on the fish mortality rate between experimental groups, while Tilapia against Clarias shows fair and Top Minnow against Clarias shows slight. In order to determine the significant difference among the treatments, one-ways ANOVA and multiple comparisons (or Duncan range multiple comparisons) were employed which is summarised in table 4 and 3. 
International Journal of Advances in Scientific Research and Engineering (ijasre), Vol 5 (4), April-2019

Table 4. ANOVA and multiple comparisons (LSD) results of Fish mortality rate between experimental groups

\begin{tabular}{|c|c|c|c|c|c|c|c|}
\hline \multirow{2}{*}{$\begin{array}{c}\text { ANOVA } \\
\text { F-cal } \\
\text { (p-value) }\end{array}$} & \multirow{2}{*}{$\begin{array}{l}\text { (I) 1=Tilapia; } \\
\text { 2=Top Minnow; } \\
\text { 3=Clarias }\end{array}$} & \multirow{2}{*}{$\begin{array}{l}(\mathrm{J}) \\
\text { 1=Tilapia; } \\
\text { 2=Top } \\
\text { Minnow; } \\
\text { 3=Clarias }\end{array}$} & \multirow{2}{*}{$\begin{array}{r}\text { Mean } \\
\text { Differe } \\
\text { nce (I- } \\
\text { J) }\end{array}$} & \multirow[t]{2}{*}{$\begin{array}{r}\text { Std. } \\
\text { Error }\end{array}$} & \multirow[t]{2}{*}{$\begin{array}{c}\text { p-value } \\
\text { (Sig.) }\end{array}$} & \multicolumn{2}{|c|}{$\begin{array}{l}\text { 95\% Confidence } \\
\text { Interval }\end{array}$} \\
\hline & & & & & & $\begin{array}{l}\text { Lower } \\
\text { Bound }\end{array}$ & $\begin{array}{l}\text { Upper } \\
\text { Bound }\end{array}$ \\
\hline \multirow{6}{*}{$\begin{array}{c}6.537 \\
(0.004)\end{array}$} & \multirow[t]{2}{*}{1.00} & 2.00 & 1.75000 & 0.99112 & $0.087^{*}$ & -0.2665 & 3.7665 \\
\hline & & 3.00 & 3.58333 & 0.99112 & $0.001 * * *$ & 1.5669 & 5.5998 \\
\hline & \multirow[t]{2}{*}{2.00} & 1.00 & $\begin{array}{r}- \\
1.75000\end{array}$ & 0.99112 & $0.087^{*}$ & -3.7665 & .2665 \\
\hline & & 3.00 & 1.83333 & 0.99112 & $0.073^{*}$ & -0.1831 & 3.8498 \\
\hline & \multirow[t]{2}{*}{3.00} & 1.00 & $\begin{array}{r}- \\
3.58333\end{array}$ & 0.99112 & $0.001^{* * *}$ & -5.5998 & -1.5669 \\
\hline & & 2.00 & $\begin{array}{r}- \\
1.83333\end{array}$ & 0.99112 & $0.073 * * *$ & -3.8498 & .1831 \\
\hline
\end{tabular}

Footnote: $\operatorname{sig}$. at $*=10 \%, * *=5 \%$ and $* * *=1 \% ; \mathrm{X}=$ Tilapia; Y=Top Minnow; $\mathrm{Z}=$ Clarias

The result in Table 4. shows significance difference between the experimental fish morality rate at all significance levels, since the F-calculated was 6.537 with p-value of 0.004 . Furthermore, three comparison (LSD) shows significance difference between the experimental fish morality rate at 5\%, while other three comparison shows significance difference at $10 \%$.

Table 5. Multiple comparisons (Duncan) results of Fish mortality rate between experimental groups

\begin{tabular}{|l|c|c|c|}
\hline \multirow{2}{*}{} & \multirow{2}{*}{$\begin{array}{c}\text { 1=Tilapia; 2=Top Minnow; } \\
\text { 3=Clarias }\end{array}$} & \multicolumn{2}{|c|}{ Subset for alpha = 0.05 } \\
\cline { 3 - 4 } & 3.00 & Group 1 & Group 2 \\
\hline Duncan $^{\mathrm{a}}$ & 2.00 & 0.0833 & \\
\cline { 2 - 4 } & 1.00 & 1.9167 & 1.9167 \\
\cline { 2 - 4 } & Sig. & $0.073 *$ & $.087 * 667$ \\
\cline { 2 - 4 } & & & 3.6667 \\
\hline
\end{tabular}

Footnote: $*=$ The mean difference is significant at the 0.10 level and Uses Harmonic Mean Sample Size $=12.000$

Table 5. displayed means for treatment groups into homogeneous subsets. It show that fish mortality rate between experimental groups can be divided into two homogeneous subsets groups which are significance difference at $10 \%$. These results indicated that tilapia and top minnow are similar, and also top minnow and clarias are similar.

\section{CONCLUSION AND RECOMMENDATION}

Sound has a lot of usefulness to man. These include; talking, music, communication, security and safety alarm source, vibrospectral analysis in machine for fault finding, Ultra sonic medical diagnosis and acoustic therapy, but it becomes a challenge and a silent killer if not well managed. The study established that noise of 87 Decibel $(d B A) \pm 5$ can affect mortality of fish over time by an increase reaction mechanism which in turn increases the bio-oxygen demand. claries or catfish tend to survive best of the three because it can take atmospheric oxygen directly and is highly recommended for aquaculture while setting of fish farms should be isolated from major noise source and given free room for proper ventilation. The result of table 4 shows significant difference 
between the experimental and control group in the mortality rate at P. value of 0.004 due to sound impact, but not exclusive of other environmental parameters such as temperature and dissolve oxygen rate from the autopsy.

\section{REFERENCES}

1. U.P. Ogoke, E.C. Nduka, O.E. Biu, C. Ibeachu, "A comparative study of foot measurements using receiver operating characteristics (ROC)", International journal of pure \& applied science ( scientia Africana), 1st ed., vol. 12, pp.76-88

2. Anonymous, “Ambient air quality in respect of noise, Central Pollution Control Board”, New Delhi: Schedule-Part II, Sec. 3 2000 .

3. A.B. Das, "Noise Pollution: its environmental implication and evaluation”, E-planet, vol. 4, 2006, pp.26-28.

4. J.K.S. Datta, S. Sadhu, S. Gupta, R. Saha, N.K. Mondal, and B. Mukkhopadhyay, “Assessment of noise level in Burdwan town, west Bengal”, J. Environ. Bio, vol. 27, 2006, pp.606-212.

5. S. Garg, R. Garg and R. Garg, "Environmental science and environmental studies”, Khanna Publishers: New Delhi, 2007.

6. K. Gopalkrishna, "Noise Pollution-Demand Jubilee year, International symposium on environmental agents and their biological effects", Osmania University, Hyderabad, India Int- 5-1- Int- 5.51978.

7. A.K. Gorai, and A. K. Pal, "Noise and its impact on human being: A Review”, J. Environ. Sci. Eng., vol. 48, 2006, pp.253-260.

8. C.M. Harris, “Handbook of Noise Control”, McGraw Hill: New York, 1979.

9 O. Anomohanran, and J.E.A. Osemeikhian, "Comparative Noise pollution study of some major towns in Delta State, Nigeria". Global Journal of Pure and Applied..Sciences, $2^{\text {nd }}$ ed., vol. 11, 2005, pp.285-290.

10. J.N. Dasomn, and I. O. Olamiju, "Environmental Pollution and Refinery operations in an Oil Producing region in Nigeria: A focus on Warri Petrochemical Company", Journal of Environmental Science Toxicology and Food Technology, $6^{\text {th }}$ ed., vol. 2 , 2013, pp.18-23.

11. L.G. Bluhm, N. Berglind, E. Nordlinh, and M. Rosenlun, "Road Traffic Noise and Hypertension", Occupational and Environmental Medicine, $2^{\text {nd }}$ ed., vol. 64, 2007, pp.122-126.

12. C.A. Boateng, and G.K. Amedofu, "Industrial noise pollution and its effects on the hearing capabilities of workers: A study from saw mills, printing press and com mills", African Journal of Health Sciences, $12^{\text {th }}$ ed., vol. 11, 2004, pp.55-60.

13. A.L. Bronzaft, "Noise: Combating an ubiquitous and hazardous pollutant", Noise and Health, $6^{\text {th }}$ ed., vol. 2, 2000, pp.1-8.

14. P. Debasish and B. Debasish, "Effect of road traffic noise pollution on human work efficiency in government offices, private organisations, and commercial business centres in Agartala City Using Fuzzy Expert System: A Case Study Advances in Fuzzy Systems", http:dx.doi.org/10T155/2012/828593-3344.

15. U.P. Ogoke, E.C. Nduka, O.E. Biu, C. Ibeachu, "A comparative study of foot measurements using receiver operating characteristics (ROC)", International journal of pure \& applied science ( scientia Africana), 1st ed., vol. 12, pp.76-88. 